\title{
Biotransformation of Digitoxigenin by Cochliobolus lunatus
}

\author{
Rodrigo M. Pádua, ${ }^{a}$ Alaíde B. Oliveira, ${ }^{a}$ José D. Souza Filho, ${ }^{b}$ Jacqueline A. Takahashi, ${ }^{b}$ \\ Maurício de Abreu e Silva ${ }^{c}$ and Fernão C. Braga ${ }^{* a}$ \\ ${ }^{a}$ Faculdade de Farmácia, Universidade Federal de Minas Gerais, Av. Antônio Carlos, 6627, \\ 31270-010 Belo Horizonte-MG, Brazil \\ ${ }^{b}$ Departamento de Química, Universidade Federal de Minas Gerais, Av. Antônio Carlos, 6627, \\ 31270-010 Belo Horizonte-MG, Brazil \\ ${ }^{c}$ Faculdade de Farmácia, Universidade Federal de Ouro Preto, Rua Costa Sena, 171, \\ 35400-000 Ouro Preto-MG, Brazil
}

\begin{abstract}
A reação de biotransformação da digitoxigenina (1) por Cochliobolus lunatus foi investigada. Foram realizados experimentos com duração de 4 dias, que resultaram no isolamento de quatro produtos, cujas estruturas químicas foram elucidadas como sendo $1 \beta$-hidroxidigitoxigenina (2), 7 $\beta$-hidroxidigitoxigenina (3), $8 \beta$-hidroxidigitoxigenina (4) e digitoxigenona (5). A obtenção desses produtos nas condições empregadas nunca foi anteriormente descrita. A produção da substância 4 em uma reação de biotransformação também é inédita.
\end{abstract}

The biotransformation of digitoxigenin (1) by Cochliobolus lunatus was investigated. The biotransformation reaction was carried out in a 4-day process, resulting in the isolation of four products, whose structures were elucidated as $1 \beta$-hydroxydigitoxigenin (2), $7 \beta$-hydroxydigitoxigenin (3), $8 \beta$-hydroxydigitoxigenin (4) and digitoxigenone (5). The production of these derivatives under the employed conditions has never been described so far. This is also the first report on the production of compound 4 by a biotransformation reaction.

Keywords: digitoxigenin, Cochliobolus lunatus, $1 \beta$-hydroxydigitoxigenin, $7 \beta$-hydroxydigitoxigenin, $8 \beta$-hydroxydigitoxigenin, digitoxigenone

\section{Introduction}

Enzymes are known to possess a wide substrate tolerance by keeping their exquisite catalytic properties with respect to chemo-, regio- and enantio-selectivity, playing an important role in biotransformations. ${ }^{1}$ Biotransformation reactions can be accomplished at room temperature and in aqueous medium, presenting itself as a milder alternative to classical chemical reactions, ${ }^{2-4}$ being employed for the resolution of racemates and to introduce chiral centers in substrates, among other uses. ${ }^{5}$

Fungi are eukaryotic organisms that possess enzyme systems similar to those of mammalians. They usually present highly flexible metabolism, thus accepting varied sources of carbon and nitrogen. The ecological relations of these organisms include the metabolism of different secondary compounds, a feature sustained by diversified

*e-mail: fernao@netuno.lcc.ufmg.br enzymatic systems, both intra and extra cellular, capable of carrying out numerous reactions..$^{6-8}$ Such attributes suggest fungi as suitable organisms to perform biotransformation reactions.

The biotransformation of steroidal compounds by fungi has been extensively evaluated, including reactions with cardiac glycosides (Pádua et al. ${ }^{9}$ and references herein; Table 3 of the present work). Digoxin, a Digitalis cardenolide, is still the drug of choice for the treatment of congestive heart failure, acting as a selective inhibitor of the $\mathrm{Na}^{+}, \mathrm{K}^{+}$ATPase enzyme. Biotransformation of cardenolides has been investigated either as a strategy to obtain new derivatives or to convert the A-type cardenolides into the corresponding C-type compounds, which have clinical relevance. ${ }^{9}$

The main reactions obtained so far for cardenolide biotransformation were hydroxylation in different positions of the steroidal skeleton, oxidation, glycosylation, epimerization and esterification of the hydroxyl 
group at C-3 (see Table 3 for references). Analysis of those data indicate that in general plant cell cultures hydroxylize position $5 \beta$, whereas the major hydroxylation sites carried out by fungi and bacteria are $7 \beta$ and $12 \beta$. Besides, solely plant cell cultures are capable of performing glycosylation reactions, as indicated by the reviewed literature (Table 3).

Hydroxylation reactions may be seen as a defense mechanism of fungi and are carried out by cytochrome P450 monooxygenases found in their endoplasmatic reticulum. Difficulties in isolation and stabilization of those enzymes, associated with the necessity of recycling $\mathrm{NAD}(\mathrm{P}) \mathrm{H}$ co-factors, prevent the industrial use of isolated enzymes. ${ }^{7,10}$ Intact fungus organisms are therefore alternatively employed in biotransformation reactions. ${ }^{6,11}$

The fungus Cochliobolus lunatus and its conidial anamorphous form Curvularia lanata are known for their capacity of hydroxylating $\Delta^{4-5}$ steroids. ${ }^{12}$ The substrate induced 11ß-hydroxylation of steroids is a classical biotransformation reaction carried out by this fungus, which tolerates structure variation in substrates. Apart from $11 \beta$ position ("normal binding"), the major sites for $C$. lunatus hydroxylation are $14 \alpha$ and $7 \alpha$ resulting from inverted and reverse inverted binding of enzyme to steroid, respectively. ${ }^{13}$

Within this context, the main goal of the present work was to evaluate the biotransformation reaction of the cardenolide digitoxigenin by $C$. lunatus and to compare the hydroxylation sites with those previously described for other steroids.

\section{Materials and Methods}

\section{General}

${ }^{1} \mathrm{H}$ NMR, ${ }^{13} \mathrm{C}$ NMR, ${ }^{1} \mathrm{H}-{ }^{1} \mathrm{H}$ COSY and HMQC spectra were recorded on a Bruker DRX-400 spectrometer $\left({ }^{1} \mathrm{H}\right.$ $400 \mathrm{MHz}$ and ${ }^{13} \mathrm{C} 100 \mathrm{MHz}$ ) using TMS as internal standard for both nuclei. Chemical shifts $(\delta)$ are given in ppm and $J$ couplings in Hertz (Hz). Optical rotations were measured with Perkin Elmer 341 polarimeter.

\section{Chemicals}

Acetonitrile chromatographic grade LiChrosolv and digitoxin were obtained from Merck (Germany). Water was purified using a Milli- $\mathrm{Q}^{50}$ purification system (Millipore, USA). Digitoxigenin, $[\alpha]_{\mathrm{D}}+197^{\circ}\left(\mathrm{CH}_{2} \mathrm{Cl}_{2}\right.$; c.0.14), employed in the biotransformation experiments, was obtained by hydrolysis of digitoxin as previously described by Pádua et al. ${ }^{9}$

\section{Biotransformation experiments}

The filamentous fungus Cochliobolus lunatus (CCT0271/ NRRL 2178) was obtained from Fundação André Tosello, Coleção de Culturas Tropicais (CCT), Campinas, SP, Brazil (http://www.cct.org.br/sdms.cgi). Before the biotransformation experiment, the fungus culture was incubated in malt agar $2 \%, \mathrm{pH} 6.5$ adjusted with $1 \mathrm{~mol} \mathrm{~L}^{-1} \mathrm{NaOH}$, for 7 days, at room temperature.

A total of 14 erlenmeyer flasks $(300 \mathrm{~mL})$, each containing $100 \mathrm{~mL}$ of sterile medium (composition: $2.0 \%$ glucose, $0.5 \%$ peptone, $0.3 \%$ yeast extract and $0.5 \%$ $\mathrm{KH}_{2} \mathrm{PO}_{4}, \mathrm{pH}$ adjusted to 5.7), was inoculated with fresh fungal suspension. After $24 \mathrm{~h}$ incubation, digitoxigenin (1) $(10 \mathrm{mg})$ was dissolved in DMF $(1 \mathrm{~mL})$ and added to each flask, following incubation at room temperature (24$\left.26{ }^{\circ} \mathrm{C}\right)$, under stirring $(200 \mathrm{rpm})$ for 4 days. The total amount of digitoxigenin (1) submitted to biotransformation was $140 \mathrm{mg}$. Control experiments containing medium plus substrate $(\mathrm{C}-1)$ and medium plus fungus culture (C-2) were carried out in each case. After removing the mycelium by filtration, the biotransformation products were sequentially extracted with chloroform $(2 \times 100 \mathrm{~mL})$ and chloroform/2-propanol $(3: 1)(100 \mathrm{~mL})$ in a separator funnel and the solvent was vacuum removed at $50{ }^{\circ} \mathrm{C}$, until residue. The obtained residues were combined $(296$ $\mathrm{mg}$ ) and analyzed by TLC (acetone:chloroform: dichlormethane; 50:35:15; Kieselgel 60G; $0.1 \mathrm{~mm} ; 20 \times$ $20 \mathrm{~cm}$, Merck). In sequence, the combined residues were submitted to purification on a Shimadzu HPLC semipreparative system (Japan) composed of pump SCL-8A and integrator C-R4A. Portions of the combined residues $(20 \mathrm{mg})$ were dissolved in $\mathrm{MeOH}(1.0 \mathrm{~mL})$ for the injection into the apparatus. An ODS column $(250 \times 20 \mathrm{~mm}$ i.d., Shimadzu, Japan) was employed at room temperature, eluted with $84 \%$ aqueous $\mathrm{CH}_{3} \mathrm{CN} / \mathrm{H}_{2} \mathrm{O}$ (46:54), at a flow rate of $5.0 \mathrm{~mL} \mathrm{~min}^{-1}$ and $\mathrm{UV}_{220}$ detection. This procedure resulted in the isolation of compounds 2 ( $\mathrm{R}_{\mathrm{t}}: 20.18 \mathrm{~min}$, $4.0 \mathrm{mg}, 2.9 \%$ yield) and $5\left(\mathrm{R}_{\mathrm{t}}: 45.30 \mathrm{~min}, 5.0 \mathrm{mg}, 3.6 \%\right.$ yield), along with a mixture of $\mathbf{3}$ and $\mathbf{4}$, eluted as partially superimposed bands ( $\left.\mathrm{R}_{\mathrm{t}}: 27.75-28.85 \mathrm{~min}, 11.0 \mathrm{mg}\right)$. The mixture of $\mathbf{3}$ and $\mathbf{4}$ was further submitted to flash chromatography on a silica gel column (Pharmacia $100 \times$ $10 \mathrm{~mm}$ i.d, silica gel 60, 0.040-0.063 mm, Merck), employing dichlormethane:acetonitrile (75:25) as eluent, at a flow rate of $2.3 \mathrm{~mL} / \mathrm{min}$, and resulted in the isolation of 3 (2.5 mg, 1.8\% yield) and 4 (5.0 mg, 3.6\% yield). All biotransformation products were isolated as colourless needles after crystallization from $\mathrm{ACN}: \mathrm{H}_{2} \mathrm{O}(9: 1$, compounds 2 and 5) and $\mathrm{CH}_{3} \mathrm{OH}$ (compounds 3 and 4). Optical rotation was determined in $\mathrm{CH}_{2} \mathrm{Cl}_{2}$ solution, at 
$20{ }^{\circ} \mathrm{C}$ : compound $2[\alpha]_{\mathrm{D}}:+56^{\circ}$ (c. 0.04$) ; 3[\alpha]_{\mathrm{D}}:+278^{\circ}$ (c. 0.195$) ; 4[\alpha]_{\mathrm{D}}:+162^{\circ}$ (c. 0.36$), 5[\alpha]_{\mathrm{D}}:+228^{\circ}$ (c.0.195).

\section{Results and Discussion}

TLC analysis of the combined residues from digitoxigenin transformation (1) by $C$. lunatus, employing Kedde as spray reagent, showed spots with distinct $\mathrm{R} f$ values of 1 solely for the biotransformation reaction, i.e., no product was observed for controls $\mathrm{C} 1$ and $\mathrm{C} 2$, as expected.

Chromatographic separation of the combined residues from biotransformation experiments of $\mathbf{1}$ resulted in the isolation of four compounds, along with the recovery of part of the starting material digitoxigenin (1). The structures of the products were defined based on spectroscopic analysis, using digitoxigenin (1) as model compound, and also by comparison with spectral data reported for the compounds or structurally related cardenolides.

The ${ }^{1} \mathrm{H}$ NMR spectrum of compound 2 showed a complex profile and the only signals easily assigned were those of $\mathrm{H}-3 \alpha(\delta 4.13), \mathrm{H}-21(\delta 5.03$ and 4.91), H-22
( $\delta 5.89), \mathrm{H}-18(\delta 0.88)$ and $\mathrm{H}-19(\delta 1.09)$, thus confirming the presence of the C-3 hydroxyl group, the integrity of the $\alpha, \beta$ unsaturated lactone ring at $\mathrm{C}-17$ and the methyl groups in the steroidal structure. The hydroxylation site was suggested by the paramagnetic shift observed for $\mathrm{H}-$ $19(\delta$ 1.09) in comparison to digitoxigenin $(1)(\delta 0.96)$, pointing out the hydroxylation position close to C-19 (Table 1). The presence of a broad signal at $\delta 3.76$ was also indicative of an additional hydroxyl group.

The HMQC spectrum obtained for $\mathbf{2}$ allowed determining ${ }^{1} \mathrm{H} /{ }^{13} \mathrm{C}$ one-bond shift correlations of all hydrogen-bearing carbon atoms in the compound. Correlation spots between C-1 / C-2 ( $\delta 29.6$ / 27.9) and their corresponding hydrogens $\mathrm{H}-1 \alpha$ and $\mathrm{H}-1 \beta(\delta 1.49$ and 1.49 ) / H-2 $\alpha$ and $\mathrm{H}-2 \beta$ ( $\delta 1.53$ and 1.53 ) were clearly observed in the HMQC spectrum of model compound $\mathbf{1}$. On the other hand, those cross-peaks were absent in the equivalent region of $\mathrm{HMQC}$ spectrum of $\mathbf{2}$, indicating their shift resulting from hydroxylation at $\mathrm{C}-1$ or $\mathrm{C}-2$.

The COSY spectrum was helpful for assigning ${ }^{1} \mathrm{H}$ NMR chemical shifts of $\mathbf{2}$ and also disclosed the precise site of hydroxylation. Hence, the sign of a methine hydrogen at

Table 1. ${ }^{1} \mathrm{H}$ NMR assignments of digitoxigenin (1) and its biotransformation products (2-5)

\begin{tabular}{|c|c|c|c|c|c|c|c|c|c|c|}
\hline \multirow[t]{2}{*}{ Hydrogen } & \multicolumn{2}{|c|}{1} & \multicolumn{2}{|c|}{2} & \multicolumn{2}{|c|}{3} & \multicolumn{2}{|c|}{4} & \multicolumn{2}{|c|}{5} \\
\hline & $\delta / \mathrm{ppm}$ & $J / \mathrm{Hz}$ & $\delta / \mathrm{ppm}$ & $J / \mathrm{Hz}$ & $\delta / \mathrm{ppm}$ & $J / \mathrm{Hz}$ & $\delta / \mathrm{ppm}$ & $J / \mathrm{Hz}$ & $\delta / \mathrm{ppm}$ & $J / \mathrm{Hz}$ \\
\hline $1 \alpha$ & 1.49 & & 3.76 & $J_{1 \alpha, 2 \alpha}=2.4$ & 1.51 & & 1.53 & & 1.59 & $J_{1 \alpha, 2 \beta}=14.4$ \\
\hline $1 \beta$ & 1.49 & & - & & 1.48 & & 1.53 & & 1.46 & $J_{1 \beta, 2 \beta}=5.5$ \\
\hline $2 \alpha$ & 1.53 & & 1.74 & & 1.48 & & 1.45 & & 2.21 & \\
\hline $2 \beta$ & 1.53 & & 1.87 & $J_{2 \beta, 1 \alpha}=2.4$ & 1.54 & & 1.63 & & 2.34 & $J_{2 \beta, 2 \alpha}=14.4$ \\
\hline $3 \alpha$ & 4.13 & & 4.13 & & 4.01 & & 4.04 & & - & \\
\hline $4 \alpha$ & 1.89 & & 2.04 & & 1.82 & & 1.83 & & 2.13 & \\
\hline $4 \beta$ & 1.34 & & 1.46 & & 1.49 & & 1.35 & & 2.62 & $J_{4 \beta, 4 \alpha}=14.2$ \\
\hline $5 \beta$ & 1.78 & & 2.05 & & 1.70 & & $1.75^{\mathrm{a}}$ & & 1.84 & $J_{5 \beta, 4 \beta}^{4 \beta, 4 \alpha}=14.2$ \\
\hline $6 \alpha$ & 1.30 & & 1.36 & & 1.49 & $J_{6 \alpha, 7 \alpha}=4.9$ & 2.21 & & 1.44 & \\
\hline $6 \beta$ & 1.87 & & 1.86 & & 1.90 & & 2.21 & & 1.86 & \\
\hline $7 \alpha$ & 1.71 & & 1.82 & & 3.90 & $J_{7 \alpha, 6 \beta}=10.6$ & 1.52 & & 1.82 & \\
\hline $7 \beta$ & 1.25 & & 1.25 & & - & & 1.38 & & 1.36 & \\
\hline $8 \beta$ & 1.56 & & 1.67 & $J_{8 \beta, 9 \alpha}=12.0$ & 1.71 & $J_{8 \beta, 7 \alpha}=10.4$ & - & & 1.63 & \\
\hline $9 \alpha$ & 1.62 & & 1.60 & $J_{9 \alpha, 11 \alpha}=12.0$ & 1.88 & & $1.82^{\mathrm{a}}$ & & 1.76 & \\
\hline $11 \alpha$ & 1.46 & & 1.44 & & 1.45 & & 1.33 & & 1.52 & \\
\hline $11 \beta$ & 1.46 & & 1.36 & $J_{11 \beta, 9 \alpha}=4.4$ & 1.31 & & 1.70 & & 1.32 & \\
\hline $12 \alpha$ & 1.40 & & 1.44 & & 1.48 & & 1.47 & & 1.47 & \\
\hline $12 \beta$ & 1.53 & & 1.50 & & 1.50 & & 1.53 & & 2.03 & \\
\hline $15 \alpha$ & 2.13 & & 2.18 & & 2.24 & & 2.23 & & 2.15 & \\
\hline $15 \beta$ & 1.71 & & 1.74 & & 1.88 & & 1.80 & & 1.73 & \\
\hline $16 \alpha$ & 2.16 & $J_{16 \alpha, 17 \alpha}=4.8$ & 2.17 & $J_{16 \alpha, 17 \alpha}=5.6$ & 2.19 & $J_{16 \alpha, 17 \alpha}=5.2$ & 2.18 & $J_{16 \alpha, 17 \alpha}=5.4$ & 2.18 & $J_{16 \alpha, 17 \alpha}=5.4$ \\
\hline $16 \beta$ & 1.87 & & 1.87 & & 1.96 & & 1.83 & & 1.92 & \\
\hline $17 \alpha$ & 2.79 & $J_{17 \alpha, 16 \beta}=8.8$ & 2.82 & $J_{17 \alpha, 16 \beta}=8.8$ & 2.85 & $J_{17 \alpha, 16 \beta}=9.0$ & 2.83 & $J_{17 \alpha, 16 \beta}=9.0$ & 2.80 & $J_{17 \alpha, 16 \beta}=9.2$ \\
\hline 18 & 0.88 & & 0.88 & & 0.90 & & 1.05 & & 0.91 & \\
\hline 19 & 0.96 & & 1.09 & & 1.00 & & 1.11 & & 1.03 & \\
\hline $21 \mathrm{a}$ & 5.00 & $J_{21 \mathrm{a}, 21 \mathrm{~b}}=18.1$ & 5.03 & $J_{21 \mathrm{a}, 21 \mathrm{~b}}=18.4$ & 5.10 & $J_{21 \mathrm{a}, 21 \mathrm{~b}}=18.3$ & 5.10 & $J_{21 \mathrm{a}, 21 \mathrm{~b}}=17.9$ & 4.99 & $J_{21 \mathrm{a}, 21 \mathrm{~b}}=18.0$ \\
\hline $21 b$ & 4.81 & & 4.91 & & 4.92 & & 4.93 & & 4.81 & \\
\hline 22 & 5.87 & $J_{22,21}=1.3$ & 5.89 & $J_{22,21}=1.6$ & 5.88 & $J_{22,21}=1.5$ & 5.88 & $J_{22,21}=1.7$ & 5.90 & $J_{22,21}=1.6$ \\
\hline
\end{tabular}

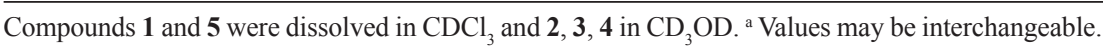


$\delta 3.76$ showed cross-peaks with $\mathrm{C}-2$ methylene hydrogens $(\delta 1.74$ and 1.87$)$, whereas $\mathrm{C}-3$ methine proton $(\delta 4.13)$ showed correlation with both $2-\mathrm{CH}_{2}(\delta 1.74$ and 1.87) and $4-\mathrm{CH}_{2}(\delta 2.04$ and 1.46). These correlations clearly indicated the hydroxylation site at $\mathrm{C}-1$.

Further evidence of the hydroxylation position was given by comparing carbon chemical shifts obtained for compound 2 and those previously reported for $1 \beta$-hydroxy$17 \beta$-H-digitoxigenin. ${ }^{14}$ The values showed close correspondence, except for the chemical shifts of C-12, C-16, C-17 and C-18, what was expected result since 2 and $1 \beta$-hydroxy-17 $\beta$-H-digitoxigenin are epimers at C-17. Furthermore, carbon chemical shits obtained for 2 were similar to those of digitoxigenin (1), with the exception of C-1 ( $\delta$ 74.9), C-2 ( $\delta$ 33.2), C-3 ( $\delta$ 69.6), C$5(\delta$ 32.0) and $\mathrm{C}-19(\delta$ 19.6), which presented either paramagnetic or diamagnetic shifts, attributed to $\alpha-, \beta$ and $\gamma$-effects, resulting from the hydroxylation at $\mathrm{C}-1$.

The stereochemistry of the hydroxylation site was indicated by the vicinal coupling constant of H-1 $(J=2.4$ $\mathrm{Hz}$ ), which pointed out the axial position for the C-1 hydroxyl group. Based on these findings, the structure of compound $\mathbf{2}$ was defined as $1 \beta$-hydroxydigitoxigenin, also named acovenosigenin A. ${ }^{15}$

Acovenosigenin A and its glycosides have been isolated from different plant species and also as a product of biotransformation reactions. ${ }^{16-19}$ NMR data previously reported showed good agreement with those of compound 2. As a result of the small amount of $\mathbf{2}$ isolated in the present work, ${ }^{13} \mathrm{C}$ NMR data were obtained indirectly by HMQC experiment. Therefore, it was not possible to attribute the resonances of non-hydrogenated carbons (Table 2).

${ }^{13} \mathrm{C}$ NMR spectrum of compound 3 presented 23 signals, disclosed by DEPT-135 experiment as two methyl, nine methylene, seven methine and five non hydrogenated carbons. Compound 3 presents a methine signal at $\delta$ 71.3, not found in the spectrum of digitoxigenin (1), indicating that hydroxylation occurred at a methylene group. Besides, a signal with chemical shift typical of C-7 $(\delta$ 21.2) or $\mathrm{C}-11(\delta 21.3)$ in digitoxigenin (1) was absent in compound 3. Compounds $\mathbf{1}$ and $\mathbf{3}$ present equivalent chemical shift values for $\mathrm{C}-12$ (Table 2 ); hence, it is very unlikely that hydroxylation had occurred at $\mathrm{C}-11$, since $\beta$ effect would result in diamagnetic shift of C-12.

Therefore, compound $\mathbf{3}$ is the hydroxylation product of digitoxigenin at C-7, what can be confirmed by the chemical shift $(\delta 3.90)$ and coupling constants of H-7 $(J=10.6,10.4$ and $4.9 \mathrm{~Hz}$ ), consistent with two trans diaxial and one axialequatorial coupling. Altogether these data allowed identifying compound $\mathbf{3}$ as $7 \beta$-hydroxydigitoxigenin. As
Table 2. ${ }^{13} \mathrm{C}$ NMR assignments of digitoxigenin (1) and biotransformation products (2-5)

\begin{tabular}{|c|c|c|c|c|c|}
\hline \multirow[t]{2}{*}{ Carbon } & \multicolumn{5}{|c|}{$\delta / \mathrm{ppm}$} \\
\hline & 1 & 2 & 3 & 4 & 5 \\
\hline 1 & 29.6 & 74.9 & 30.4 & 28.9 & 39.8 \\
\hline 2 & 27.9 & 33.2 & 28.3 & 28.9 & 37.1 \\
\hline 3 & 66.8 & 69.6 & 67.3 & 67.6 & 212.3 \\
\hline 4 & 33.3 & 34.6 & 35.2 & 34.3 & 42.1 \\
\hline 5 & $36.0^{\mathrm{b}}$ & 32.0 & 36.0 & $37.0^{\mathrm{b}}$ & 43.6 \\
\hline 6 & 26.5 & 27.6 & 37.7 & 23.8 & 26.5 \\
\hline 7 & $21.2^{\mathrm{c}}$ & 22.6 & 71.3 & 32.4 & 21.0 \\
\hline 8 & 41.8 & 43.1 & 47.5 & 77.7 & 41.7 \\
\hline 9 & $35.5^{\mathrm{b}}$ & 38.9 & 38.3 & $38.0^{\mathrm{b}}$ & 36.7 \\
\hline 10 & 35.4 & n.a. & 36.3 & 36.5 & 35.2 \\
\hline 11 & $21.3^{\mathrm{c}}$ & 22.6 & 22.4 & 18.9 & 21.2 \\
\hline 12 & 40.0 & 41.0 & 40.8 & 41.5 & 36.7 \\
\hline 13 & 49.6 & n.a. & 50.6 & 52.0 & 49.6 \\
\hline 14 & 85.5 & n.a. & 86.8 & 87.0 & 85.3 \\
\hline 15 & 33.1 & 33.6 & 34.8 & 35.8 & 33.2 \\
\hline 16 & 26.9 & 28.4 & 27.8 & 28.1 & 26.9 \\
\hline 17 & 51.0 & 52.2 & 52.3 & 53.2 & 50.8 \\
\hline 18 & 15.7 & 16.0 & 16.6 & 18.8 & 15.8 \\
\hline 19 & 23.7 & 19.6 & 24.2 & 26.3 & 22.5 \\
\hline 20 & $174.5^{\mathrm{d}}$ & n.a. & $177.3^{\mathrm{a}}$ & $177.2^{\mathrm{a}}$ & $174.1^{\mathrm{a}}$ \\
\hline 21 & 73.4 & 75.5 & 75.4 & 75.3 & 73.4 \\
\hline 22 & 117.6 & 118.0 & 117.8 & 117.9 & 117.9 \\
\hline 23 & $174.4^{\mathrm{d}}$ & n.a. & $178.4^{\mathrm{a}}$ & $178.4^{\mathrm{a}}$ & $174.3^{\mathrm{a}}$ \\
\hline
\end{tabular}

Compounds 1 and 5 were dissolved in $\mathrm{CDCl}_{3}$ and 2, 3, 4 in $\mathrm{CD}_{3} \mathrm{OD}$.

a-d Values may be interchangeable; $n$.a. $=$ not assigned (see text for details).

expected, ${ }^{1} \mathrm{H}$ NMR spectrum of $\mathbf{3}$ was similar to that of digitoxigenin (1), apart from the diamagnetic shifts observed for $\mathrm{H}-7 \alpha(\delta$ 3.90), H-6 $\alpha(\delta$ 1.49), H-6 $\beta(\delta$ 1.90) and $\mathrm{H}-8 \beta(\delta 1.71)$, resultant from the vicinity of the $7 \beta$-hydroxyl group (Table 1). Assignment of these hydrogens was confirmed by data of the HMQC spectrum.

Further confirmation of the hydroxylation site at C-7 was furnished by analysis of the COSY spectrum, which showed cross-peaks between $\mathrm{H}-7 \alpha(\delta$ 3.90) both with $6-\mathrm{CH}_{2}(\delta 1.90$ and 1.49$)$ and $\mathrm{C}-8$ methine proton $(\delta 1.71)$.

${ }^{13} \mathrm{C}$ and DEPT-135 NMR spectra of 4 revealed two methyl, ten methylene, five methine and six non hydrogenated carbons. The signal at $\delta 77.7$ in the spectrum of 1 disappeared in the DEPT-135 spectrum of $\mathbf{4}$, suggesting the occurrence of hydroxylation at a methine group. Comparison of ${ }^{13} \mathrm{C} \mathrm{NMR}$ spectrum obtained for compound $\mathbf{4}$ and digitoxigenin (1) showed that the signal attributed to $\mathrm{C}-8(\delta 41.8)$ in the later, was absent in the first. Consequently, compound $\mathbf{4}$ was identified as $8 \beta$-hydroxydigitoxigenin. As expected, ${ }^{1} \mathrm{H}$ NMR spectra of 4 and digitoxigenin (1) were similar, excluding the signals attributed to $\mathrm{H}-6 \alpha(\delta 2.21), \mathrm{H}-6 \beta(\delta 2.21), \mathrm{H}-7 \alpha$ $(\delta 1.52), \mathrm{H}-7 \beta(\delta 1.38), \mathrm{H}-9 \alpha(\delta 1.75$ or 1.82$), \mathrm{H}-11 \alpha$ $(\delta 1.33), \mathrm{H}-11 \beta(\delta 1.70), \mathrm{H}-18(\delta 1.05)$ and $\mathrm{H}-19(\delta 1.11)$, which showed distinct values, due to the influence of the 
Table 3. Biotransformation reactions of digitoxigenin and digitoxin (Dt) carried out by cell cultures

\begin{tabular}{|c|c|c|c|c|c|c|c|c|c|}
\hline \multirow[t]{2}{*}{ Cell cultures } & \multirow[t]{2}{*}{ Source } & \multirow{2}{*}{$\begin{array}{c}\text { Oxidation } \\
\text { (3ß-OH } \rightarrow \\
\text { 3-ceto) }\end{array}$} & \multirow{2}{*}{$\begin{array}{c}\text { Epimeration } \\
(3 \beta-\mathrm{OH} \rightarrow \\
3 \mathrm{~A}-\mathrm{OH})\end{array}$} & \multicolumn{4}{|c|}{ Hydroxylation } & \multirow{2}{*}{$\begin{array}{r}\text { Glycosylation Isomerization } \\
(17 \beta-17 \alpha \\
\text { lactone ring) }\end{array}$} & \multirow[t]{2}{*}{ Esterification } \\
\hline & & & & $1 \beta \quad 4 \beta$ & $5 \beta \quad 7 \beta$ & $12 \beta$ & $16 \beta$ & & \\
\hline
\end{tabular}

1. Plants

Ammi visnaga

Cannabis sativa

Caspsicum frutescens

Daucus carota

Digitalis cariensis ssp. trojana

Digitalis dubia

Digitalis grandiflora

Digitalis lanata

Digitalis lutea ssp. lutea

Digitalis metonensis

Digitalis parviflora

Digitalis purpurea

Ipomoea sp.

Nerium oleander L

Panax giseng

Pergularia tomentosa

Strophanthus gratus

Strophanthus amboensis

Strophanthus intermedius

Strophanthus divaricatus

Thevetia neriifolia

2. Fungi

Absidia coerulea ${ }^{\text {a }}$

Actinomucor elegans ${ }^{b}$ ATCC 6476

Aspergillus oryzae

Chaetomium globosum MN-211

Chrysosporium merdarium $\mathrm{MN}-72$

Circinella muscae $\mathrm{MN}-120$ /

ATCC 16008

Cunninghamella blakeslleana

Fusarium avenaceum

Fusarium ciliatum $^{\mathrm{c}}$

Fusarium oxysporum f. sp. Lini ${ }^{\mathrm{d}}$

Gibberella fujikuroi

Gibberella saubinettii (Mont.) Sacc.

Gongronella butleri ${ }^{e}$

Psilocybe mexicana Heim

Psilocybe semperviva

Thammostylum piriforme ${ }^{\mathrm{f}}$

Mortierella isabellina $\mathrm{MN}-64$

Nigrospora sphaerica

Rhizopus oryzae ${ }^{\mathrm{g}}$ ATCC 11145

Rhizopus stolonifer ${ }^{\mathrm{h}} \mathrm{ATCC} 6227 \mathrm{~b}$

Trichocladium asperum $\mathrm{MN}-37 /$

ATCC 16009

Trichothecium roseum Link ATCC 8685

3. Bacteria

Streptomyces alboniger MNG** 180

Streptomyces cellulosae ATCC 3313

Streptomyces diastatochromogenes S-59

Streptomyces griseoflavus ATCC 12269

Streptomyces lividans

Streptomyces owasiensis nov. $s p$

Streptomyces praecox MNG** 127

Streptomyces purpurascens

(MNG** 176-179)

Streptomyces rimosus NRRL 2234

$[19]$
$[27]$
$[28]$
$[29-31]$
$[27]$
$[27]$
$[27]$
$[30,32-35]$
$[27]$
$[27]$
$[27]$
$[32,36-38]$
$[27]$
$[39]$
$[40]$

[19]

[14]

[41]

[42]

[43]

[33]

$[25,44-47]$

$[25,48,49]$

[50]

[51]

[51]

[51]

$[52,53]$

[54*]

$[9,48]$

$[54,55]$

[52]

[56]

[51]

[57]

[57]

[52]

[51]

[48]

$[25,45,50,58]$

[25]

[51]

[50]

[59]

[51]

[51]

[51]

[60]

[51]

[59,61]

[59]

[51]
$+(\mathrm{Dt}) \quad-\quad+(\mathrm{Dt})($ Glucose $)$

$+(\mathrm{Dt})$

$+(\mathrm{Dt})$ (Glucose)

+ (Dt)(Glucose)

+ (Dt)(Glucose)

$+;+(\mathrm{Dt}) \quad-\quad+($ Digitoxose/Glucose $)$

+ (Dt)(Glucose)

+ (Dt)(Glucose)

$+(\mathrm{Dt})($ Glucose $)$

$+(\mathrm{Dt}) \quad+;+(\mathrm{Dt})($ Glucose $)$

+ (Glucose)

+ (Glucose/ Sorforose)

$+(\mathrm{C}-3)$

(stearate/palmitate/ myristate/laurate)

+ (Glucose)

+ (Glucose)

$+($ Glucose $)$

Notes: * results cited in literature as footnote; ** number of the Hungarian National Collection of Microorganisms (Budapest). Species formerly known as: ${ }^{\mathrm{a}}$ Absidia orchidis (Vuill.) Hagen, ${ }^{\mathrm{b}}$ Mucor parasiticus, ${ }^{\mathrm{c}}$ Calonectria decora, ${ }^{\mathrm{d}}$ Fusarium lini, ${ }^{\mathrm{e}}$ Gongronella urceolifera, ${ }^{\mathrm{f}}$ Helicostylum piriforme Bainier, ${ }^{\mathrm{g}}$ Rhizopus arrihizus, ${ }^{\mathrm{h}}$ Rhizopus nigricans. 
$8 \beta$-hydroxyl group. Deshielding induced by this group imposed diamagnetic shifts to $\mathrm{H}-18$ and $\mathrm{H}-19$, due to 1,4 effect. ${ }^{20}$

The COSY spectrum of $\mathbf{4}$ did not provide additional information on the hydroxylation site, since it occurred in a methine group. On the other hand, comparison of HMQC spectra recorded for $\mathbf{1}$ and $\mathbf{4}$ clearly indicated, in the last, the absence of a cross-peak between C-8 $(\delta 41.8)$ and $\mathrm{H}-8 \beta(\delta 1.56)$ found in digitoxigenin (1). Comparison between NMR data assignments carried out for compound 4 and literature records for its glycoside ${ }^{21}$ has confirmed the structure of 4 as $8 \beta$-hydroxydigitoxigenin, also named cerdollagenin.

The major differences between ${ }^{13} \mathrm{C}$ NMR spectra of compound $\mathbf{5}$ and digitoxigenin (1) were the presence of a carbonyl carbon signal $(\delta 212.3)$ and the absence of the C-3 carbinol carbon signal $(\delta 66.8)$ in the first. In total, these data strongly suggest that compound $\mathbf{5}$ is digitoxigenone, a product from digitoxigenin oxidation at $\mathrm{C}-3$. Aside from the diamagnetic shifts observed for C-1 ( $\delta 39.8), \mathrm{C}-2$ ( $\delta 37.1), \mathrm{C}-4$ ( $\delta 42.1)$ and C-5 ( $\delta 43.6)$ in compound $\mathbf{5}$, as a result from deshielding effect of the carbonyl at C-3, ${ }^{13} \mathrm{C}$ NMR chemical shifts observed for $\mathbf{5}$

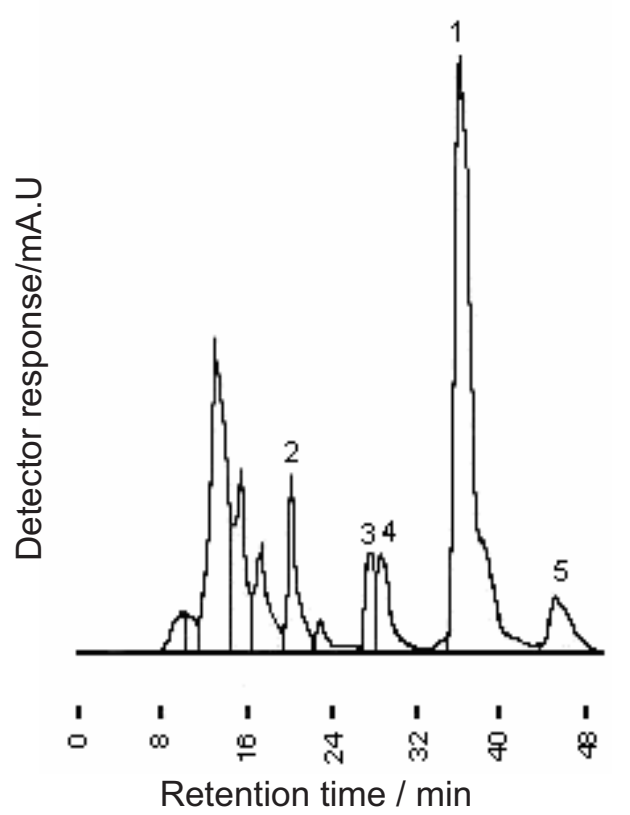

Figure 1. Semi-preparative RP-HPLC chromatogram obtained for the residue from digitoxigenin biotransformation. Identified peaks: $1=$ digitoxigenin; $2=1 \beta$-hydroxydigitoxigenin; $3=7 \beta$-hydroxydigitoxigenin; $4=8 \beta$-hydroxydigitoxigenin; 5 = digitoxigenone. Chromatographic conditions: see Materials and Methods.

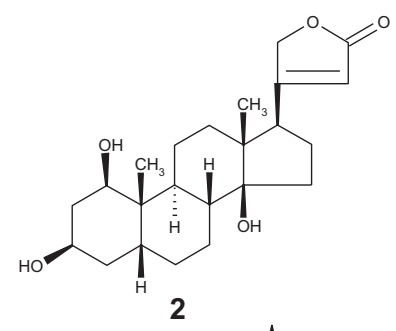

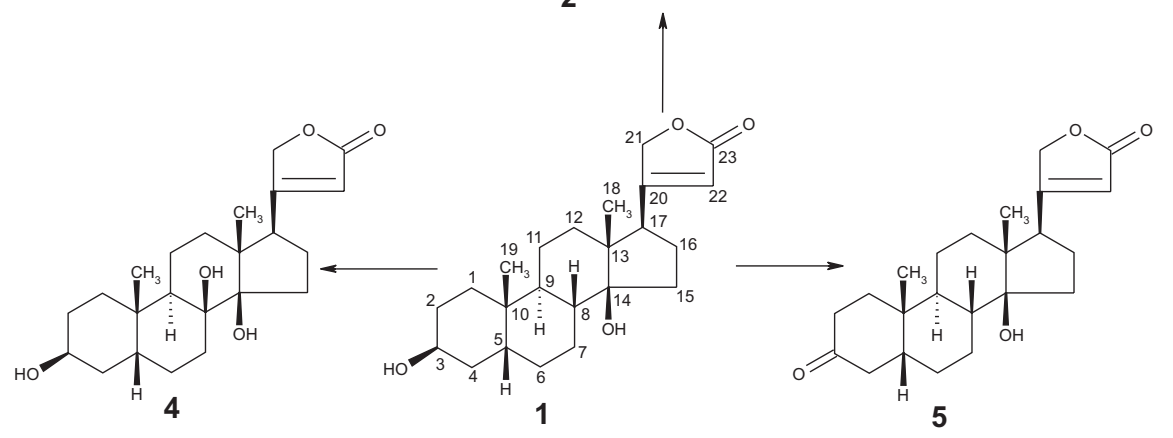

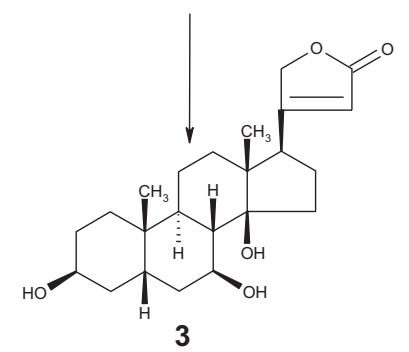

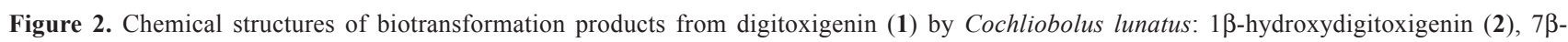
hydroxydigitoxigenin (3), 8ß-hydroxidigitoxigenin (4) and digitoxigenone (5). 
and digitoxigenin were similar. Assignments of the above mentioned carbons were attested by HMQC spectrum, whereas COSY data allowed confirming the attribution of some hydrogens. Hence, H-2 $\beta$ ( $\delta 2.34 J=14.4,14.4$ and $5.5 \mathrm{~Hz})$ showed correlation spots with $1-\mathrm{CH}_{2}(\delta 1.59$ and 1.46) and $\mathrm{H}-2 \alpha(\delta 2.21)$, while $\mathrm{H}-4 \beta(\delta 2.62 J=14.2$, and $14.2 \mathrm{~Hz})$ showed cross-peaks with 5-CH $(\delta 1.84)$ and $\mathrm{H}-4 \alpha(\delta 2.13)$. Definitive confirmation of the structure of 5 was given by comparison with NMR data previously reported for digitoxigenone. ${ }^{22}$

The biotransformation of digitoxigenin by $C$. lunatus is here reported for the first time and it afforded hydroxylated products at positions $1 \beta, 7 \beta$ and $8 \beta$. These hydroxylation sites are distinct from those previously described for $\Delta^{4-5}$ steroids in reactions with the same fungus, that usually occur at the positions $11 \beta, 14 \alpha$ and $7 \alpha{ }^{7,23,24}$ Such differences may be explained by distinct enzyme/ substrate interactions, arising from the uncommon configuration of digitoxigenin steroidal frame (cis, trans, cis), in comparison to other steroids, or due to the presence of the $\alpha, \beta$-unsaturated lactone ring at $\mathrm{C}$ - 17 . Such hypotheses consider that the same hydroxylases do participate in reactions with digitoxigenin and other steroids. In this sense, Nozaki et al. ${ }^{25}$ improved the $7 \beta$ hydroxylation of digitoxigenin by Absidia coerulea, Rhizopus oryzae and Rhizopus stolonifer after pre-incubation with progesterone and deoxycorticosterone. Such result demonstrates that monooxygenases induced by $\Delta^{4-5}$ steroids are also capable of hydroxylating digitoxigenin.

Hydroxylation of digitoxigenin at positions $1 \beta$ and $7 \beta$, as well as oxidation of its hydroxyl group at $\mathrm{C}-3$, have been previously reported for plant cell cultures and fungi (Table 3). It should be stressed, however, that this is the first report on compounds $\mathbf{2}, \mathbf{3}$ and $\mathbf{5}$ as biotransformation products of digitoxigenin by $C$. lunatus. Hydroxylation at $1 \beta$-position is of special interest considering that some glycosides of $1 \beta$-hydroxydigitoxigenin have been reported to exhibit potent in vitro activity against ovarian adenocarcinoma and lung carcinoma. ${ }^{15,}{ }^{16}$ Hence, such reaction may be employed for the future production of new bioactive cardenolide derivatives.

The $8 \beta$-hydroxylation of digitoxigenin employing a cell culture, the fungus $C$. lunatus, is here described for the first time (Table 3). Some cardiac glycosides hydroxylated at $8 \beta$-position have been isolated from the plant species Nerium oleander, Cerbera manghas and Cerbera odalamm. ${ }^{21}$ The $8 \beta$-hydroxydigitoxigenin obtained in the present work is clear evidence that $C$. lunatus hydroxylases involved in the reaction are not affected by the steric hindrance of the $14 \beta-\mathrm{OH}$ group. Therefore, it is feasible to obtain a product with two vicinal hydroxyls at $8 \beta$ and $14 \beta$-positions. Such reaction may present several synthetic applications in the future and can also lead to new bioactive cardenolides and steroid derivatives.

As a future perspective, the conditions for this biotransformation reaction have to be optimized to overcome the obstacles and to allow its application in large scale: the low aqueous solubility of digitoxigenin, which results in limited substrate accessibility to the biocatalyst, and toxicity of both substrate and product against fungus culture. ${ }^{26}$ The use of surfactants and water-miscible or immiscible solvents is suggested by several authors as a strategy to diminish these difficulties. ${ }^{26}$

\section{Acknowledgments}

This research was supported by grant CDS1203/98 from FAPEMIG (Brazil). CNPq (Brazil) is also acknowledged for research (F. C. B.) and graduate (R. M. P.) fellowships.

\section{References}

1. Faber, K.; Pure Appl. Chem. 1997, 69, 1613.

2. Leuenberger, H.G.W.; Pure Appl. Chem. 1990, 62, 753.

3. Mahato, S.B.; Garai, S.; Steroids 1997, 62, 332.

4. Fernandes, P.; Cruz, A.; Angelova, B.; Pinheiro, H.M.; Cabral, J.M.S.; Enzyme Microb. Technol. 2003, 32, 688.

5. Jeromin, G.E.; Bertau, M. Bioorganikum; Jeromin, G. E.; Bertau, M.; eds.; Wiley-VCH: Dresden, 2005, ch. 1.

6. van den Brink, H. (J.) M.; van Gorcom, R.F.M.; van den Hondel, C.A.M.J.J.; Punt, P.J.; Fungal Genet. Biol. 1998, 23, 1.

7. Vitas, M.; Smith, K.E.; Plavec, J.; Kesselmeier, J.; Pajiè, T.; Ferlan, A.; Žigon, D.; Kelly, S.L.; Komel, R.; Chemosphere 1999, 38, 853.

8. Žnidaršič, P.; Vitas, M.; Komel, R.; Pavko, A.; Physiol. Mol. Plant. Pathol. 1999, 55, 251.

9. Pádua, R.M.; Oliveira, A.B.; Souza Filho, J.D.; Vieira, G.J.; Takahashi, J.A.; Braga, F.C.; J. Braz. Chem. Soc. 2005, 16, 614.

10. Bernhardt, R.; J. Biotechnol. 2006, 124, 128.

11. Omura, T.; Biochem. Biophys. Res. Commun. 1999, 266, 690.

12. Vitas, M.; Smith, K.; Rozman, D.; Komel, R.; J. Steroid. Biochem. Mol. Biol. 1994, 49, 87.

13. Holland, H.L.; Lakshmaiah, G.; Ruddock, P.L.; Steroids 1998, 63, 484.

14. Furuya, T.; Kawaguchi, K.; Hirotani, M.; Phytochemistry 1988, 27, 2129.

15. Baek, N.I.; Lee, Y.H.; Park, J.D.; Kim, S.I.; Ahn, B.Z.; Planta Med. 1994, 60, 26. 
16. Kitanaka, S.; Takido, M.; Mizoue, K.; Nakaike, S.; Chem. Pharm. Bull. (Tokyo) 1996, 44, 615.

17. Hanna, A.G.; Elmagal, M.H.A.; Hassan, A.Z.; Duddeck, H.; Simon, A.; Kovács, J.; Tóth, G.; Magn. Reson. Chem. 1998, $36,936$.

18. Ueda, J.; Tezuka, Y.; Banskota, A.H.; Tran, Q.L.; Tran, Q.K.; Saiki, I.; Kadota, S.; J. Nat. Prod. 2003, 66, 1427.

19. El Olemy, M.M.; Elhag, H.; El Domiaty, M.; Sattar, E.A.; Al Azizi, M.M.; Al Said, M.S.; Saudi Pharm. J. 1994, $2,76$.

20. Kirk, D.N.; Toms, H.C.; Douglas, C.; White, K.A.; Smith, K.E.; Latif, S.; Hubbard, R.W.P.; J. Chem. Soc., Perkin Trans. 2 1990, 1567.

21. Abe, F.; Yamauchi, T.; Phytochemistry 1992, 31, 2459.

22. Habermehel, G. G.; Hammann, P. E.; Magn. Reson. Chem. 1985 , 23, 959 .

23. Undisz, K.; Groh, H.; Stopsack, H.; Hörhold-Schubert, C.; J. Steroid. Biochem. Mol. Biol. 1992, 43, 543.

24. Vitas, M.; Pajiè, T.; Kelly, S.L.; Komel, R.; J. Steroid. Biochem. Mol. Biol. 1997, 63, 345.

25. Nozaki, Y.; Masuo, E.; Satoh, D.; Agr. Biol. Chem. (Tokyo) 1962, 26, 398.

26. Mahato, S.B.; Majumdar, I.; Phytochemistry 1993, 34, 883.

27. Reinhard, E.; Alfermann, A.W.; Adv. Biochem. Eng. 1980, 16 , 49.

28. Rao, S. R.; Tripathi, U.; Ravishankar, G. A.; Biocatal. Biotransform. 2002, 20, 137.

29. Jones, A.; Veliky, I.A.; Ozubko, R.S.; Lloydia 1978, 41, 476.

30. Stohs, S.J.; Adv. Biochem. Eng. 1980, 16, 85.

31. Jones, A.; Veliky, I.A.; Eur. J. Appl. Microbiol. Biotechnol. 1981, 13,84 .

32 Stohs, S.J.; Rosenberg, H.; Lloydia 1975, 38, 181.

33. Döller, P.C.; Reinhard, E.; Planta Med. 1979, 37, 277

34. Kreis, W.; Hoelz, H.; May, U.; Reinhard, E.; Plant. Cell., Tiss. Organ Cult. 1990, 20, 191.

35. Theurer, C.; Kreis, W.; Reinhard, E.; Planta Med. 1998, 64, 705.

36. Furuya, T.; Hirotani, M.; Shinohara, T.; Chem. Pharm. Bull. (Tokyo) 1970, 18, 1080.

37. Alfermann, A.W.; Boy, H.M.; Döller, P.C.; Hagedorn, W.; Heins, M.; Wahl, J.; Reinhard, E. In Plant Tissue Culture and its Biotechnological Applications; Barz, W.; Reinhard, E.; Zenk, M. H.; eds., Springer: Berlin, 1977, ch. 5.

38. Hirotani, M.; Furuya, T.; Phytochemistry 1980, 19, 531.
39. Paper, D.H.; Franz, G.; Plant Cell Rep. 1990, 8, 651.

40. Kawaguchi, K.; Watanabe, T.; Hirotani, M.; Furuya, T.; Phytochemistry 1996, 42, 667.

41. Kawaguchi, K.; Hirotani, M.; Furuya, T.; Phytochemistry 1988, 27, 3475.

42. Kawaguchi, K.; Hirotani, M.; Furuya, T.; Phytochemistry 1989, $28,1093$.

43. Kawaguchi, K.; Hirotani, M.; Furuya, T.; Phytochemistry 1991, 30, 1503

44. Ishii, H.; Nozaki, Y.; Okumura, T.; Satoh, D.; Yakugaku Zasshi 1961, 81, 1051. (CA 55:144366)

45. Nozaki, Y.; Okumura, T.; Agr. Biol. Chem. (Tokyo) 1961, 25, 515 .

46. Ishii, H.; Nozaki, Y.; Okumura, T.; Satoh, D.; Chem. Pharm. Bull. (Tokyo) 1963, 11, 156.

47. Okumura, T.; Nozaki, Y.; Satoh, D.; Chem. Pharm. Bull. (Tokyo) 1964, 12, 1143.

48. Nozaki, Y.; Agr. Biol. Chem. (Tokyo) 1961, 25, 461.

49. Nozaki, Y.; Agr. Biol. Chem. (Tokyo) 1961, 25, 559.

50. Juhasz, G.; Tamm, Ch.; Helv. Chim. Acta 1961, 44, 1063.

51. Nozaki, Y.; Mayama, M.; Akaki, K.; Satoh, D.; Agr. Biol. Chem. (Tokyo) 1965, 29, 783.

52. Nawa, H.; Uchibaysahi, M.; Kamiya, T.; Yamano, T.; Arai, H.; Abe, M., Nature 1959; 184, 469.

53. Okada, M.; Hasunuma, M.; Yakugaku Zasshi 1966, 86, 67. (CA 64:68072)

54. Tamm, Ch.; Gubler, A.; Helv. Chim. Acta 1959, 42, 239.

55. Gubler, A.; Tamm, Ch.; Helv. Chim. Acta 1958, 41, 297.

56. Okada, M.; Yamada, A.; Ishidate, M.; Chem. Pharm. Bull. (Tokyo) 1960, 8, 530.

57. Weiss-Berg, E.; Tamm, Ch.; Helv. Chim. Acta 1963, 46, 2435.

58. Satoh, D.; Eitaro, M.; Nozaki, Y.; Japanese Patent 43029583 1968. (CA 70:86300)

59. Albrecht, K.; Szeleczky, Z.; Kişs, J.; Trinn, M.; Tömörkeny, E.; Balogh, T.; Ila, L.; Nagy, L.; Tölgyesi, L.; UK Patent GB2 034353 A 1979. (CA 93:43934)

60. Dahiya, J.S.; Indian J. Microbiol 1991, 31, 251.

61. Natonek, M.; Albrecht, K.; Szeleczky, Z.; Szarka, E.; Szentirmai, A.; Udvardy-Nagy, M.; Trinn, M.; Nagy, L.; Budai, M.; Kişs, J.; Trompler, A.; Balogh, T.; Tölgyesi, L.; Ila, L.; UK Patent GB2 023 144A 1979. (CA 93:68657)

Received: February 4, 2007 Web Release Date: October 8, 2007 